\title{
Eagle View Camp \\ Methods
}

\section{Research Fellow:}

Dennis Karanja, MAAK(A)

Lecturer, Department of Landscape Architecture

Jomo Kenyatta University of Agriculture and Technology

\section{Research Assistant:}

Carolyne Wanza Nthiwa, MAAK(LA)

Jomo Kenyatta University of Agriculture and Technology

\section{Firm Liaison:}

Hitesh Mehta, FASLA, FRIBA, FAAK

President

HM Design

This investigation was conducted as part of the Landscape Architecture Foundation's 2019 Case Study Investigation (CSI) program. CSI matches faculty-student research teams with design practitioners to document the benefits of exemplary high-performing landscape projects. Teams develop methods to quantify environmental, social, and economic benefits and produce Case Study Briefs for LAF's Landscape Performance Series.

To cite:

Karanja, Dennis, and Carolyne Wanza Nthiwa. "Eagle View Camp." Landscape Performance Series. Landscape Architecture Foundation, 2019. https://doi.org/10.31353/cs1521

The full case study can be found at: https://landscapeperformance.org/case-study-briefs/eagleview-camp 


\section{Overview}

Eagle View Camp in Naiboisho, located approximately $250 \mathrm{~km}$ from the capital of Kenya, Nairobi, and adjacent to the great Mara Game Reserve, is a private ecolodge that was redesigned to promote wildlife protection and conservation through minimal interference with the existing landscape and ecology of the site. The number of guest tents were increased from five to nine, and they were carefully placed within the landscape to respect the site's topography, visual corridors, flora, and fauna, thus allowing all natural systems to function uninterrupted. All trees and shrubs were left undisturbed during construction and more were planted. These were all native. The narrow gravel walkways that are carpeted with elephant dung, signage made of slate stone and ragged stone semi-walls of some of the structures were constructed with locally available material that needs no maintenance while giving the visitors an experience of the wild. The tents overlook the wild plains and are set out in a semi-circular courtyard layout giving visitors an understanding of how Maasai cultural practices have played a role in ensuring an environmentally, socially and economically sustainable relationship between the wild, landscape and community.

\section{Environmental Benefits}

\section{Preserved $100 \%$ of the project site with all disturbance confined to previously developed areas.}

Methods: Visual cues, site observation. The research team relied on interviews with key interviewees who have been on site since inception, because a Master Plan was not available for comparison. We also compared 2012 and 2017 site maps from Google Earth images.

Calculations: Screenshots from sources 
Google Earth Image as at 04/10/2012; shows the layout of the tents, roads, and walkways.

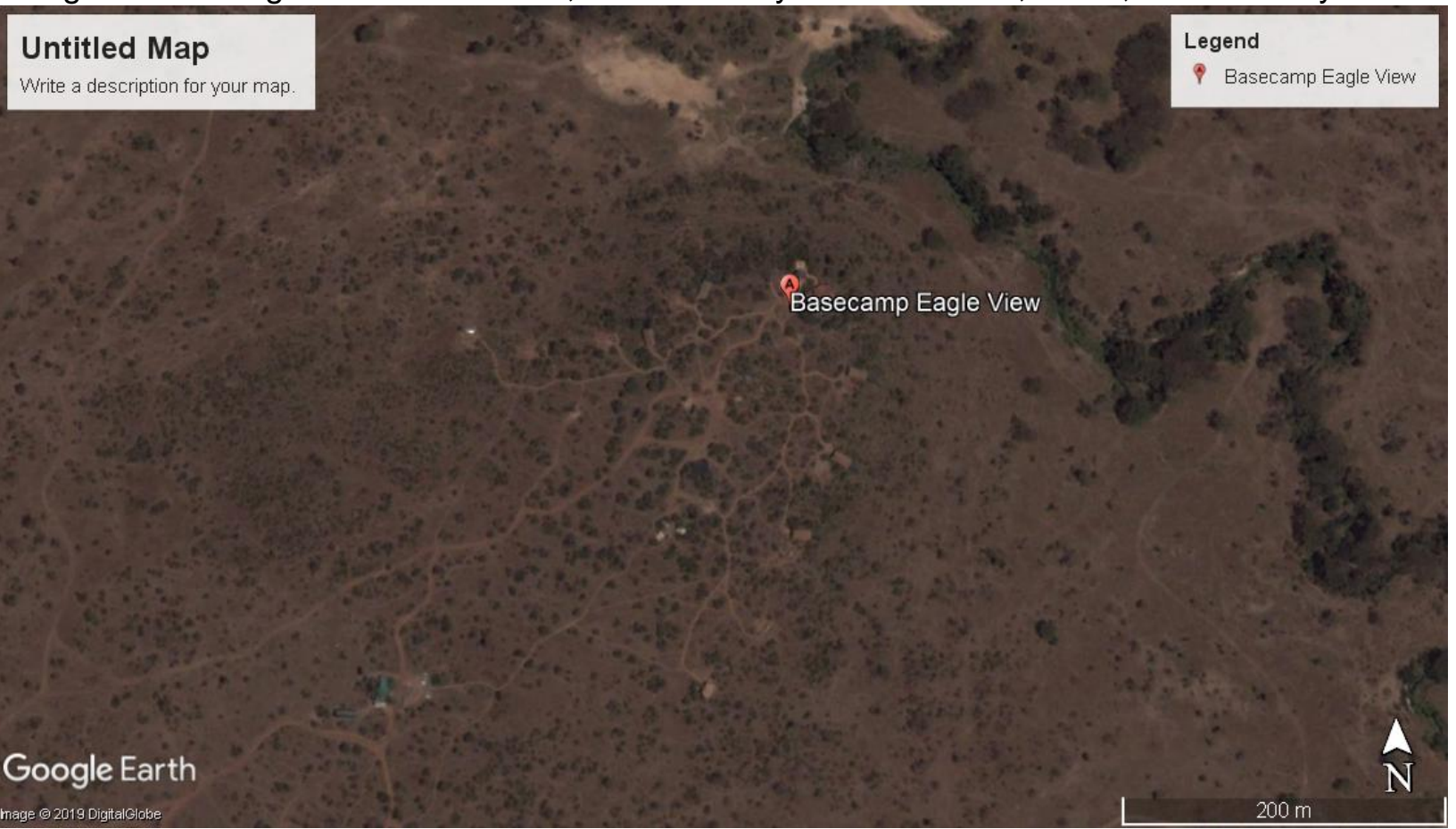

Google Earth Image as at 04/04/2017; shows the layout of the improved tents, roads and walkways, all at the same position they were in 2012.

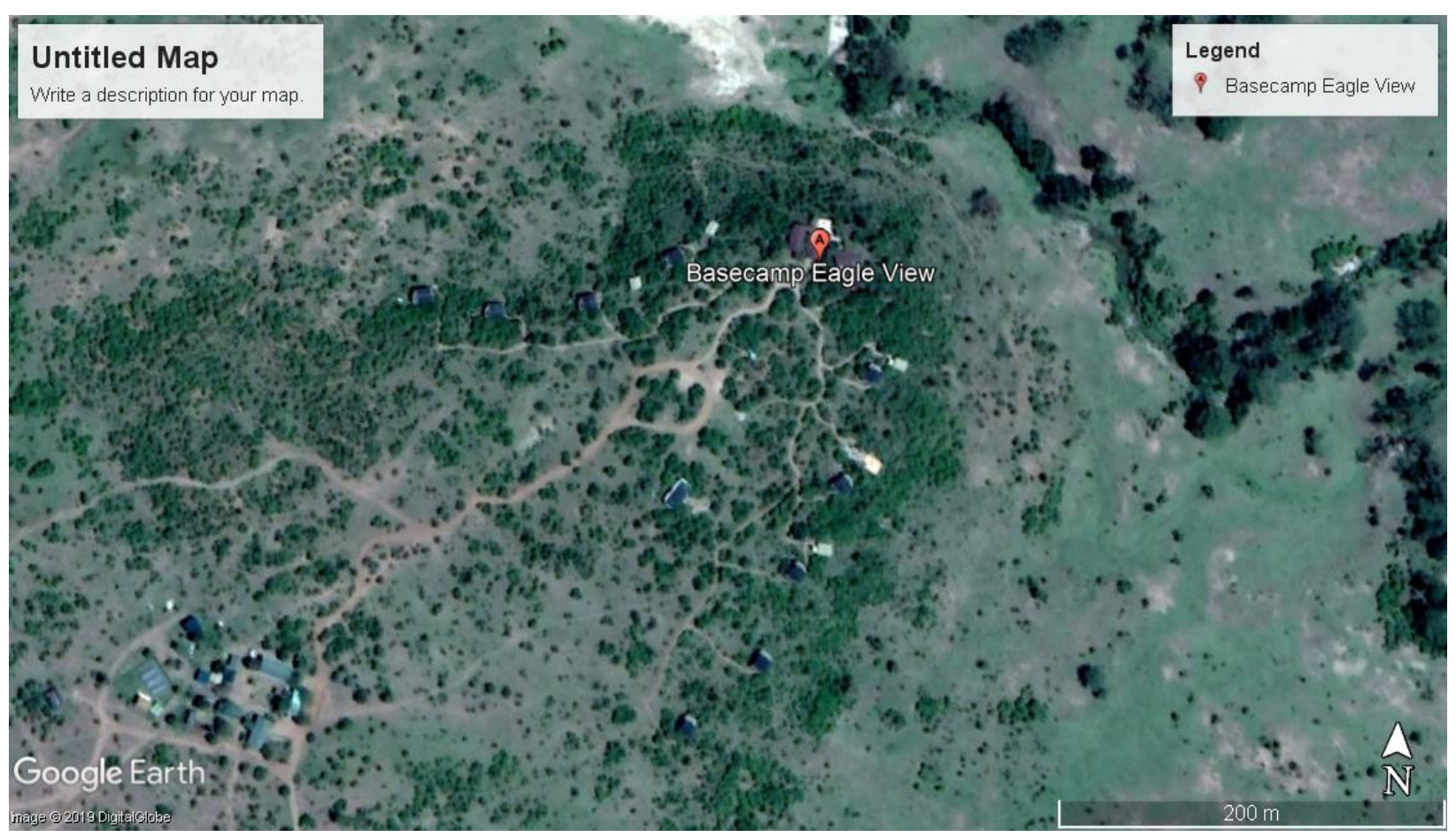

Sources: Google Earth, DigitalGlobe, accessed on 09/07/2019 
Limitations: The original Master Plan before the upgrade was not available. Research relied on ground observation and Google Earth images.

Saves an estimated 460,000 gallons of water monthly or approximately $\$ 24,000$ annually as compared to a conventional resort landscape.

Methods: The Eagle View Camp landscape does not require or receive any irrigation as the vegetation is native and naturally regenerates with the changing seasons. We compared consumption ( 0 ) to that of a conventional landscape. We worked with the rates provided for irrigating an acre of a conventional landscape and the rate of the cost of water per unit, as provided by Narok County; the jurisdiction under which the ecolodge falls.

\section{Calculations:}

\begin{tabular}{|c|c|}
\hline Item & Calculation of Expected usage \\
\hline $\begin{array}{l}\text { Area in acres } \\
\left(117,841 \mathrm{~m}^{2}\right)\end{array}$ & 29 acres \\
\hline $\begin{array}{l}\text { Liters consumed per } \\
\text { day }\end{array}$ & $\begin{array}{l}1 \text { acre }=2,000 \text { liters (equal to } 2 \mathrm{~m}^{3} \text { ) } \\
29 \text { acres }=58,000 \text { liters }\end{array}$ \\
\hline $\begin{array}{l}\text { Consumption per } \\
\text { month }\end{array}$ & $\begin{array}{l}1 \text { day }=58,000 \text { liters } \\
30 \text { days }=1,740,000 \text { liters }\end{array}$ \\
\hline $\begin{array}{l}\text { Cost per month } \\
(\$ 1=\text { Ksh. } 100)\end{array}$ & $\begin{array}{l}1000 \text { liters }=1 \mathrm{~m}^{3} \\
1,740,000 \text { liters }=1,740 \mathrm{~m}^{3} \\
1 \mathrm{~m}^{3}=\$ 1.7 \\
1,740 \mathrm{~m}^{3}=\$ 2,958\end{array}$ \\
\hline $\begin{array}{l}\text { Cost per annum } \\
(\$ 1=\text { Ksh.100) }\end{array}$ & $\begin{array}{l}1 \text { month }=\$ 2,958 \\
8 \text { months }=\$ 23,664 \\
\text { (The region receives rainfall in the months of April, May, June, and } \\
\text { October; hence no irrigation is needed in those four months) }\end{array}$ \\
\hline
\end{tabular}

\section{Sources:}

Water Services Regulatory Board, WASREB. "Narok", https://wasreb.go.ke/narok/ (accessed July 26, 2019).

Limitations: There are no standard rates for irrigating a "typical" landscape; the rate used was an average of consultation with private irrigation companies in the country. The method also assumed that irrigation would be required every day considering that the ecolodge is an arid and semi-arid area. 
Saves 4,202 kWh of electricity monthly, approximately \$11,000 per year, by changing from exclusive use of diesel fuel generators to solar panels with diesel fuel only used for back-up energy. This reduces carbon emissions from power generation by $71 \%$.

Methods: Compared the current overall energy use of the site to that of before the upgrade.

\section{Calculations:}

\begin{tabular}{|c|c|c|}
\hline Item & Before & After \\
\hline Energy Source & 50 kva Generator & $\begin{array}{l}50 \text { kva generator and Solar } \\
\text { Power }\end{array}$ \\
\hline $\begin{array}{l}\text { Amount of fuel spent } \\
\text { per week }\end{array}$ & 210 litres of diesel & 60 litres of diesel (for back-up) \\
\hline $\begin{array}{l}\text { Cost of fuel per week } \\
\text { (price is } \$ 1.1 / \text { litre) }\end{array}$ & $210 \times \$ 1.1=\$ 231$ & $60 \times 1.1=\$ 66$ \\
\hline $\begin{array}{l}\text { Cost of fuel per month } \\
\text { (one month }=4 \text { weeks) }\end{array}$ & $\$ 231 \times 4=\$ 924$ & $\$ 66 \times 4=\$ 264$ \\
\hline $\begin{array}{l}\text { Electricity }(\mathrm{kWh}) \\
\text { consumed per month } \\
\text { (rate is in December } \\
2012 \text { was } \$ 0.1732 \text { per } \\
\mathrm{kWh} \text { and in December } \\
2018 \text { was } \$ 0.2217 \text { ) }\end{array}$ & $934 / 0.1732=5,393 \mathrm{kWh}$ & $264 / 0.2217=1,191 \mathrm{kWh}$ \\
\hline $\begin{array}{l}\text { Electricity saving per } \\
\text { month }\end{array}$ & \multicolumn{2}{|c|}{$5,393 \mathrm{kWh}-1,191 \mathrm{kWh}=\underline{4,202 \mathrm{kWh}}$} \\
\hline $\begin{array}{l}\text { Cost saving per } \\
\text { annum }\end{array}$ & \multicolumn{2}{|l|}{$\begin{array}{l}1 \mathrm{month}=4,202 \mathrm{kWh} \\
12 \text { months }=50,424 \mathrm{kWh} \\
1 \mathrm{kWh}=\$ 0.2217 \\
\underline{\mathbf{5 0 , 4 2 4} \mathbf{k W h}=\$ \mathbf{1 1 , 1 7 9}}\end{array}$} \\
\hline
\end{tabular}

Fuel used per week = 210 litres

CO2emission from diesel fuel- $2.6 \mathrm{~kg}$ per litre

$210 \times 2.6 \mathrm{Kg}=546 \mathrm{Kg}$ per week

$546 \mathrm{Kg}$ of $\mathrm{CO} 2 \times 52=28,392 \mathrm{Kg}$ of $\mathrm{CO} 2$ per year

Reduced oil consumption to 60 litres

$210-60=150$ i.e. 150 litres saving per week

Translates to;

$150 \times 2.6 \mathrm{Kg}=390 \mathrm{Kg} \mathrm{CO} 2$ per week

Annually $390 \mathrm{Kg} \times 52=\underline{20,280 \mathrm{Kg} \mathrm{CO} 2}$.

Reduction of emissions;

$20,280 / 28,392 \times 100=\underline{71.42 \%}$ 


\section{Sources:}

Basecamp Explorer, energy use information.

Regulus Limited. "Electricity cost in Kenya" https://stima.regulusweb.com/ (accessed July 15, 2019).

J.M.K.C. Donev et al. (2015). Energy Education - Diesel generator

[Online]. https://energyeducation.ca/encyclopedia/Diesel generator. [Accessed: July 27, 2019].

Limitations: The fluctuation of United States Dollar versus that of Kenya Shillings affects the price of petroleum. Hence, the above figures are based on average estimates.

Increased vegetation cover by $108 \%$ and supported an increase in individual buffalo by $26 \%$, elephants by $72 \%$, and giraffes by $26 \%$ in the wider Mara Naboisho.

Methods: Used Google Earth images, GIS analysis and Graphisoft ArchiCAD software. Areas of the vegetation cover of before and after were established and a percentage of the increase derived. Increased animal species presence from Basecamp Explorer Foundation estimates from 2014-2017 within the Mara Naboisho Conservancy.

\section{Calculations:}

2012 Map

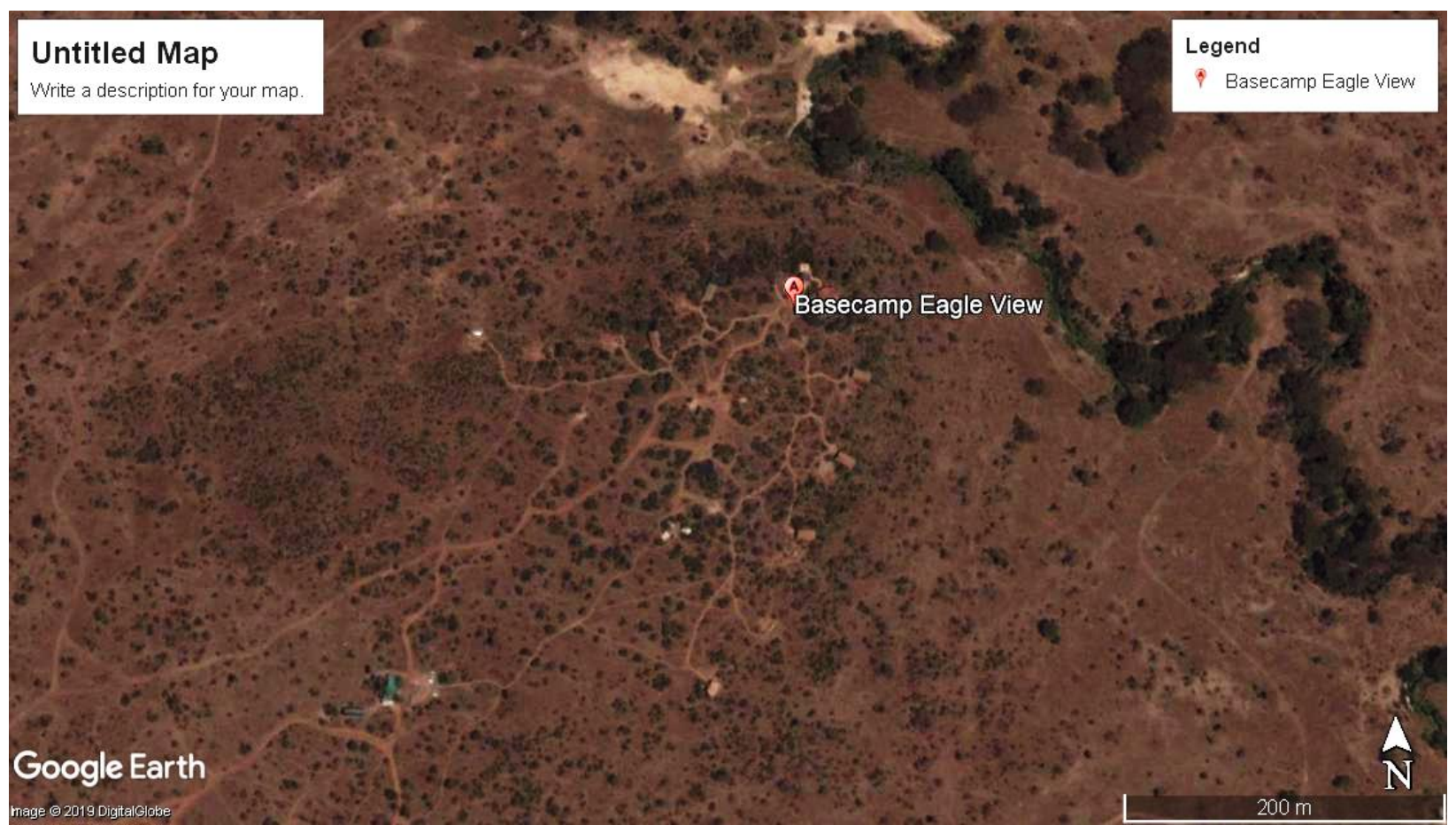




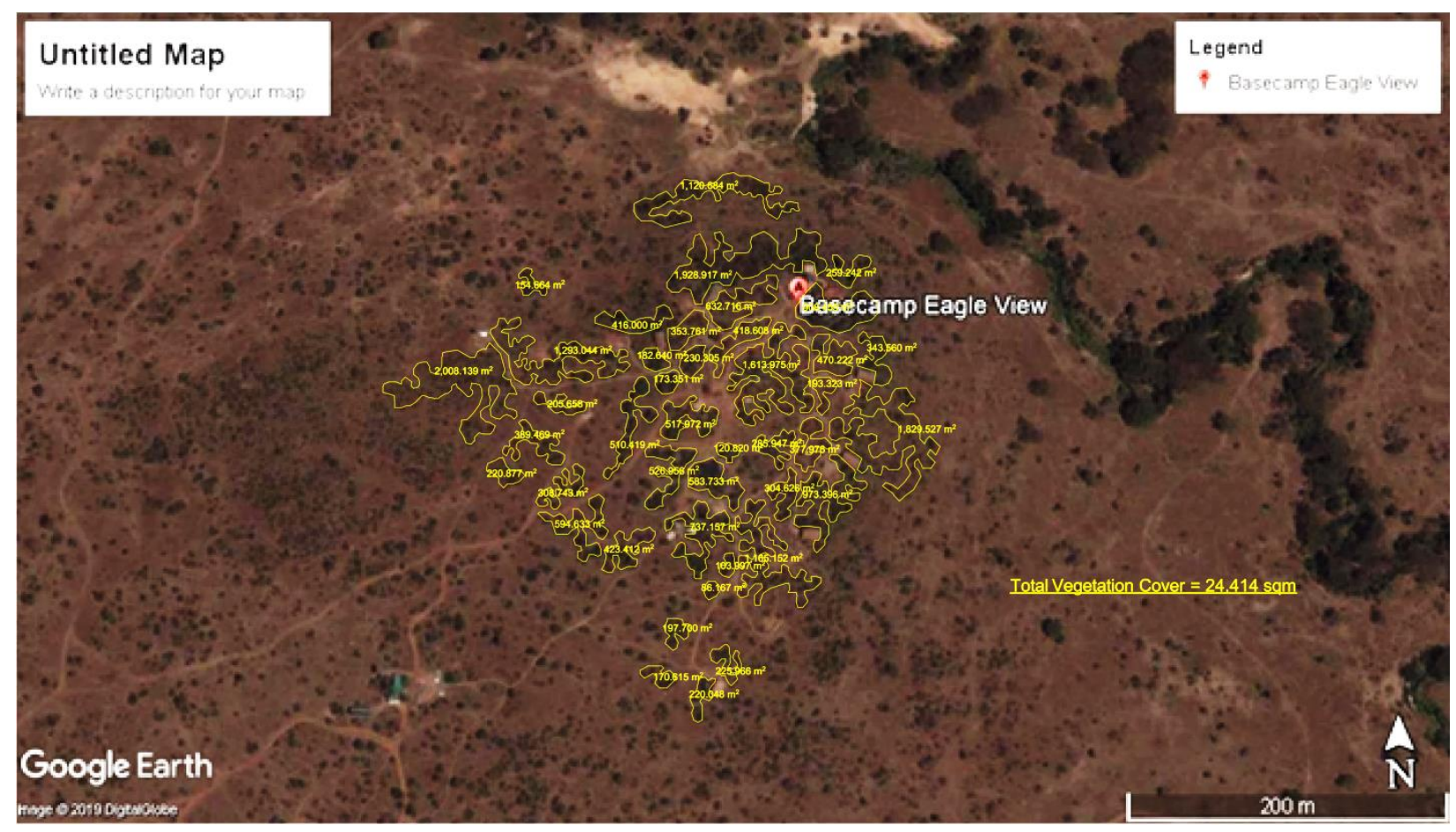

2012 Vegetation cover was $24,314 \mathrm{~m}^{2}$

\section{Map}

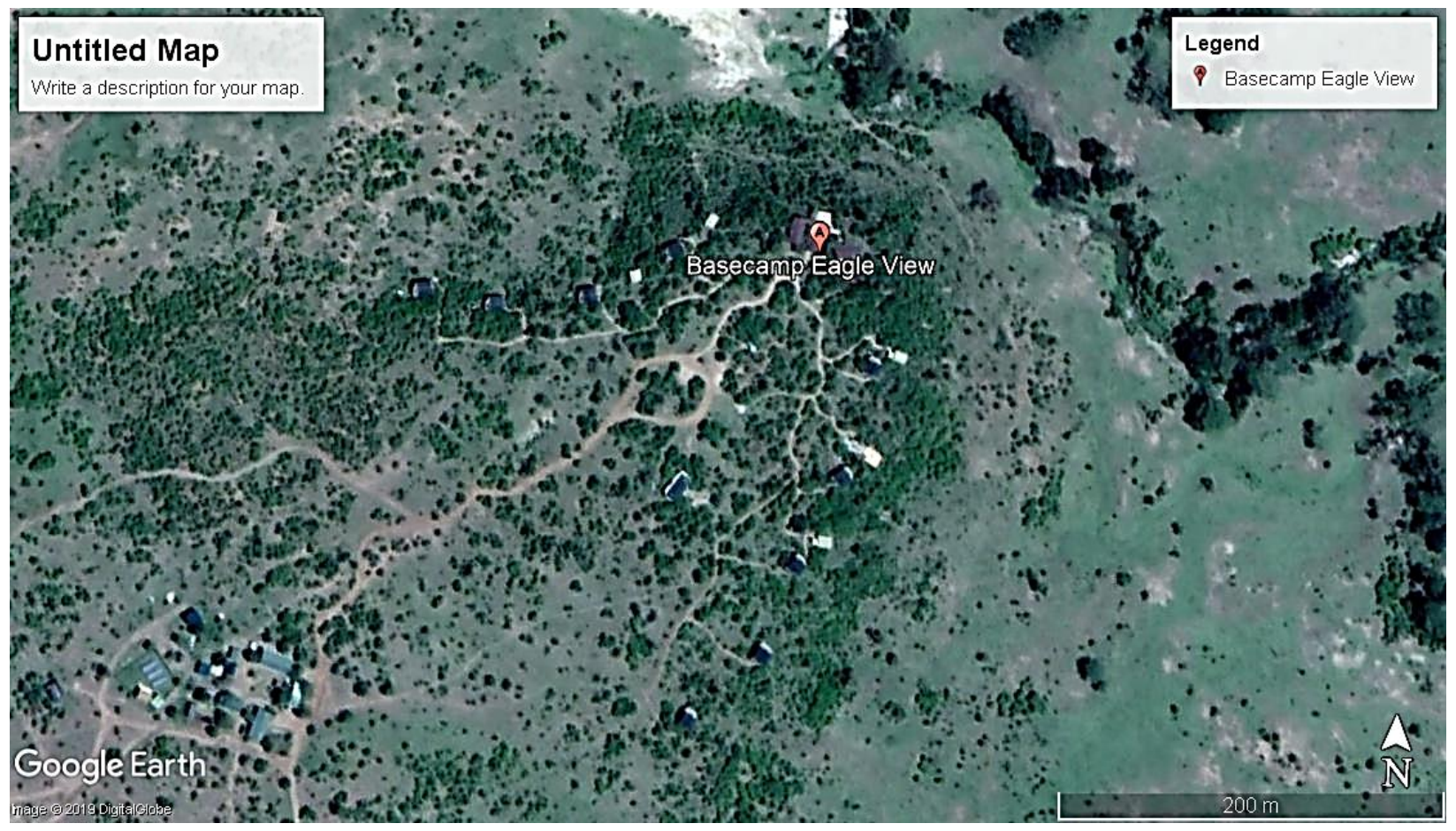




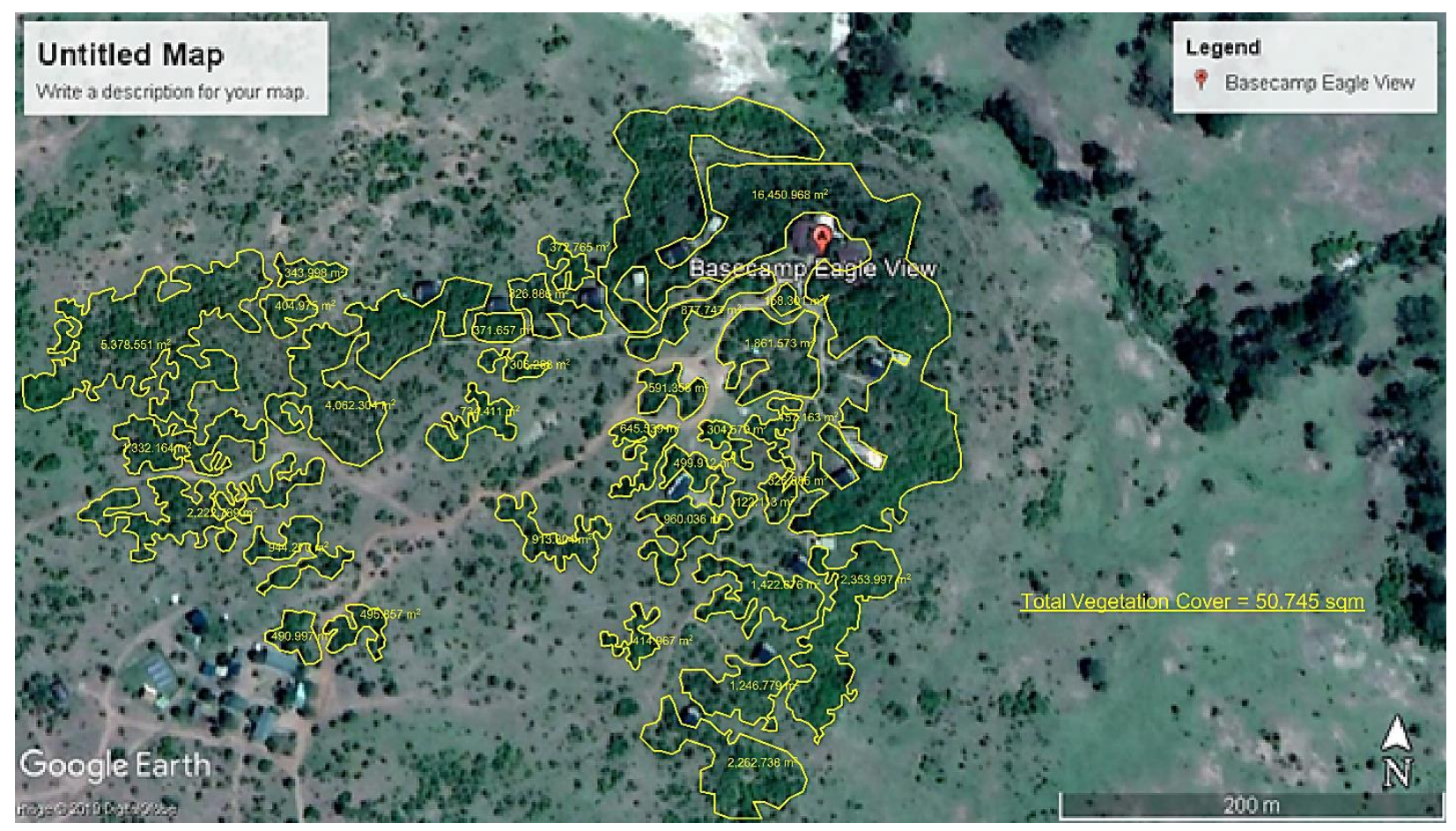

2017 Vegetation cover was $50,745 m^{2}$; this is $108 \%$ increase from 2012.

\section{Sources:}

Google Earth Pro. (April 04, 2017 and October 04, 2017). Basecamp Eagle View, C12, Naboisho, Kenya. 1024'11.75"S, 35020'39.64"E, Eye alt 2.88 km.

DigitalGlobe 2019. https://www.google.com/earth/versions/\#earth-pro [July 09, 2019]. Basecamp Explorer Foundation. Mara Naboisho Conservancy - Sustainability Report May 2018. https://www.basecampexplorer.com/foundation/report/mara-naboisho-conservancysustainability-report-may-2018/

Limitations: Vegetation covered area was an estimate sourced from Google Earth Pro application. The latest image was last taken in April 2017 two years prior to this research. Eagle View Camp was only a contributing factor to the increase in animal numbers, but can be assumed to have contributed significantly through increased habitat creation and incentivizing the local community to not use land for alternate uses.

\section{Social Benefits}

\section{Perceived as significantly preserved by $100 \%$ of 21 surveyed community members who were familiar with the site before the project.}

Methods: Conducted a survey of site users to determine whether they felt that the site was significantly preserved. The surveyed users were the community members since they were familiar with the site before and after the upgrade. 
Calculations: see sample interview schedule in the appendix.

Sources: field data collection; interview schedules.

Limitations: The only users who were familiar with the site before the upgrade were the community members who lived near the site and later were employed with the ecolodge. The findings did not consider visitors, most of whom would be unfamiliar with the site before the redesign.

Perceived as visually appealing according to $100 \%$ of 36 surveyed users including community members, management, and visitors.

Methods: Conducted a survey of site users and visitors to determine whether and to what degree the design intervention changed their perceptions about scenic quality or aesthetic value.

Calculations: see sample interview schedule in the appendix.

Sources: field data collection; interview schedules.

Limitations: The sample size is limited.

\section{Economic Benefits}

Saves $\$ 7$ per day, an estimated \$29,000 annually, on a per-visitor basis in operations and maintenance costs.

Methods: Compared estimated amount of money spent per visitor for maintenance, labor activities, and fuel costs of before and after. The cost of maintenance was reduced due to the use of locally sourced natural materials that do not require maintenance (especially for the landscape).

Calculations:

\begin{tabular}{|l|l|l|}
\hline Item & Before & After \\
\hline Number of visitors & 1,097 & 4,158 \\
\hline $\begin{array}{l}\text { Maintenance cost per } \\
\text { visitor/day }\end{array}$ & $\$ 25$ & $\$ 18$ \\
\hline $\begin{array}{l}\text { Maintenance cost per } \\
\text { visitor/annum }\end{array}$ & $\begin{array}{l}1 \text { day }=\$ 25 \\
356 \text { days }=\$ 27,425\end{array}$ & $\begin{array}{l}1 \text { day }=\$ 186 \text { days }=\$ 74,844 \\
3\end{array}$ \\
\hline
\end{tabular}




\begin{tabular}{|l|l|}
\hline Cost saving per annum & $\begin{array}{l}\text { If the numbers before were also 4,158, then the savings would be } \\
\$ 7 \text { per visitor. Hence; } \\
4,158 \times \$ 7=\$ \mathbf{2 9 , 1 0 6}\end{array}$ \\
\hline
\end{tabular}

Sources: field data collection; interview with operator and manager in charge during construction.

Limitations: The operator allowed us to access the worksheets for their day-to-day operation costs but could not allow us to attach the same for this research.

\section{Saved an estimated \$378,000 in materials, labor, and transport costs during construction.}

Methods: Compared cost of materials, labor and transport needed to construct with estimation of what would be needed if all the ecolodge materials were conventional and outsourced.

\section{Calculations:}

\begin{tabular}{|c|c|c|}
\hline Item & Expected Cost (conventional) & Actual Cost \\
\hline Cost of materials & $\begin{array}{l}\$ 50,190 \\
\text { (sand } \$ 4,914, \text { Aggregate } \\
\$ 4,536 \text { and walkways } \$ 40,740 \text { ) }\end{array}$ & $\$ 0$ \\
\hline $\begin{array}{l}\text { Cost of transporting } \\
\text { materials }\end{array}$ & $\begin{array}{l}3 \text { ton }=1 \text { trip } \\
189 \text { ton }=84 \text { trips } \\
\text { Cost/trip = } \$ 179 \\
\text { Therefore; } \\
84 \times \$ 179=\$ 15,036\end{array}$ & $\$ 0$ \\
\hline $\begin{array}{l}\text { Cost of labor for the } \\
\text { entire project }\end{array}$ & $\begin{array}{l}\text { No. of laborers }=240 \\
\text { Duration/month }=28 \text { days } \\
\text { No. of months }=6 \\
\text { Income/day }=\$ 14 \\
\text { Total cost for } 6 \text { months; } \\
240 \times 28 \times 6 \times 14=\$ 564,480\end{array}$ & $\begin{array}{l}\text { No. of laborers }=240 \\
\text { Duration/month }=28 \text { days } \\
\text { No. of months }=6 \\
\text { Income/day }=\$ 6 \\
\text { Total cost for } 6 \text { months; } \\
240 \times 28 \times 6 \times 6=\$ 241,920\end{array}$ \\
\hline $\begin{array}{l}\text { Total cost } \\
(1 \text { USD = Ksh. } 83.6 \text { in } \\
\text { July, 2012) }\end{array}$ & $\begin{array}{l}\$ 40,740+\$ 15,036+\$ 564,480 \\
=\$ 620,256\end{array}$ & $\$ 241,920$ \\
\hline Total cost of saving & \multicolumn{2}{|l|}{$\$ 620,256-\$ 241,920=\$ 378,336$} \\
\hline
\end{tabular}


Sources: field data collection; interview with operator and manager in charge during construction.

Limitations: The operator allowed us to access the worksheets for their day-to-day operation costs but could not allow us to attach the same for this research.

Generates an estimated $\$ 70,000$ annually for the local community; $\$ 50,000$ from ecolodge fees and \$20,000 through sale of beads. Additionally, an estimated 600 families are supported through land leases.

Methods: Determined annual revenue that goes to local community from fees charged at the site and sale of bead products sold by the community women's group. The project donates $\$ 50,000$ annually; this goes directly into supporting Koiyaki Guiding School as well as the primary schools serving the community.

Calculations: field data collection; interview with operator and manager in charge during construction.

Sources: field data collection; interview with operator and operations manager in charge.

Limitations: We could not independently verify these numbers.

Created 240 jobs during construction, and 26 new permanent and 18 temporary jobs after construction. The project also supports 150 women through a local beading group, which indirectly supports 600 people.

Methods: Determined the number of permanent or seasonal staff positions created through management records.

Sources: field data collection; interview with operator and operations manager in charge. https://www.basecampexplorer.com/foundation/story/ [Accessed: July 25, 2019].

Limitations: It was not possible to follow up with all the beneficiaries of the project. 